\title{
Non-Compliance In Schizophrenia From Socio-Cultural, Familial And Environmental Perspective.
}

\author{
Dhungana $\mathrm{M}^{1}$, Ghimire $\mathrm{SR}^{2}$, Thapa $\mathrm{M}^{2}$
}

1. Lecturer, Department of Psychiatry, Devdaha Medical College and Research Institute, Rupandehi, Nepal 2. Consultant Psychiatrist, Chautari Nepal Health Foundation, Manigram, Rupandehi, Nepal

E-mail *Corresponding author:drdhungana3536@ hotmail.com

\section{Abstract}

Introduction: Non-compliance significantly influences the course and outcome of treatment. Non-compliance in Schizophrenia is common and a major challenge globally due to need of long duration of treatment and other related factors. The objective of study was to identify patients with treatment non-compliance and associated factors in schizophrenia from socio-cultural, familial and environmental perspective.

Material And Method: This study identified non-compliance in schizophrenia among 80 patients attending outpatient department at department of psychiatry, Devdaha Medical College, Rupandehi, Nepal. The study was a descriptive cross section study and purposive sampling, a type of non-random sampling technique was utilized for study. Ethical consideration was done throughout the study and informed consent was taken prior to the study. The questionnaire was given to those patients who had insight into the illness and who were able to understand the questions in the pro forma. Informants of patients with poor insight were given questionnaire to complete.

Results: Out of 80 participants, majorities (57.5\%) were male and $42.5 \%$ were female in the ratio 1.35:1. The mean age of respondent was 30.2 \pm 11.6 . Approximately one seventh $(13.75 \%)$ of them were illiterate, more than half $(61.25 \%)$ had family income less than Nepalese rupees 10,000 a month. A significant proportion (15\%) of family members did not know the role of them and relatives, and majority $(76.25 \%)$ said that people contribute negatively. The different factors contributing to non-compliance were belief as non treatable illness (20\%), significant life events (2.5\%), migration (3.75\%), lack of access of treatment nearby $(72.5 \%)$, forget doctor appointment $(11.25 \%)$, cessation of medication as per advise of faith healer (10\%), stop medicine due to social stigma (15\%), not monitoring patient on medication (15\%) and discontinuation of treatment on refusal $(11.25 \%)$.

Conclusion: The study explored noncompliance in Schizophrenia from socio-cultural, familial and environmental perspectives. Multiple factors were identified that contributed for non-compliance directly or indirectly. The noncompliance is a preventable condition that needs an emphasis from different perspectives.

\section{Keywords: Compliance, Non-Compliance, Schizophrenia, Nepal}

\section{INTRODUCTION}

Schizophrenia is a complex, chronic and disabling illness and its characteristic symptoms include delusions, hallucinations, disorganized speech or behaviour, impaired cognitive ability ${ }^{1}$ and negative symptoms (loss of motivation, social withdrawal, affective flattening, restricted emotional experience and expression, poverty of speech, reduced hedonic capacity.) ${ }^{2}$ It has approximately $1 \%$ life time risk and people of younger age groups are usually affected by this illness. ${ }^{3}$ Non-compliance in Schizophrenia is common and a major challenge globally due to need of long duration of treatment and other 
related factors. ${ }^{4}$ Non-compliance or nonadherence to treatment is the degree to which a patient does not carry out the clinical recommendations of a treating doctor. ${ }^{5}$ There is no exact definition of non-compliance in schizophrenia, ${ }^{4}$ however, Zygmunt and his colleagues suggested that non-compliance in Schizophrenia is the complete cessation of medication for the duration of at least one week. ${ }^{6}$

A number of factors are found associated with non-compliance in Schizophrenia including social, cultural, familial and environmental. Stigma associated with mental illness is prevailing in Nepalese society, ${ }^{7}$ and it has strong impact on treatment compliance. Several past studies revealed association of non compliance with poor knowledge about need of long term treatment, ${ }^{8}$ poor family support, ${ }^{9}$ stigma associated with illness, ${ }^{10,11}$ financial difficulties/poverty, ${ }^{12}$ lack of treatment access nearby and lack of carer. ${ }^{13}$ It is evident that the reasons for non-compliance in Schizophrenia are multi factorial in origin. ${ }^{4}$ We conducted this study to identify the related factors for noncompliance from socio-cultural, familial and environmental perspective.

\section{MATERIAL AND METHOD}

This descriptive cross- sectional study was conducted in Department of Psychiatry, Devdaha Medical College, Rupandehi, Nepal. The study sample comprised a total of 80 patients with Schizophrenia. Purposive sampling, a type of non-random sampling was utilized for the study. The male patients of age of 18 years and above presenting in our hospital with symptoms consistent with Schizophrenia were screened by pre-defined criteria. Patients who fulfilled the ICD-10 14 diagnosis of Schizophrenia were included in the study. Other inclusion criteria were intake of error dose, treatment drop out and discontinuation of medication seven or more days. Following the detailed description of the study to all family members and patients, written informed consent was obtained for each individual. Questionnaire was given to patient who had insight and who were able to perform. Informants of patients with poor insight were given questionnaire to complete. Data were entered manually into statistical package for social science (SPSS-20) and then it was analyzed by using descriptive statistics in term of frequency and percentage. Interpretation of the study was done on the basis of analyzed data using tables.

\section{RESULT}

The total 80 patients were evaluated for noncompliance of which majorities (57.5\%) were male and $42.5 \%$ were female in the ratio 1.35:1. The mean age of respondent was 30.2 \pm 11.6 . Table 1 explored the socio-demographic characteristics of patients. Table 2 and 3 revealed socio-cultural, familial and environmental factors associated with noncompliance.

Table 1: Demographic Characteristics ( $n=80)$

\begin{tabular}{|l|l|l|}
\hline Variables & Frequency & Percentage \\
\hline Age & 32 & \\
18-25 yrs & 24 & 40 \\
26-35 yrs & 15 & 30 \\
36-45yrs & 9 & 18.75 \\
>45yrs & & 11.25 \\
\hline Gender & 46 & 57.5 \\
Male & 34 & 42.5 \\
Female & & \\
\hline Religion & 50 & 62.5 \\
Hindu & 20 & 25 \\
Muslim & 8 & 10 \\
Buddhist & 2 & 2.5 \\
Christian & & \\
\hline Occupational Status & 13 & 16.25 \\
Agriculture & 16 & 20 \\
Business & 18 & 22.5 \\
Service & 10 & 12.5 \\
Daily wages & 12 & 15 \\
Student & 11 & 13.75 \\
Homemaker & & \\
\hline Educational Status & 11 & 13.75 \\
Illiterate & 69 & 86.25 \\
Literate & & \\
\hline Family income & 18 & 22.5 \\
Below NRs 5000 & 31 & 38.75 \\
NRs. 5000-10000 & 16 & 20 \\
NRs. 10000-20000 & 15 & 18.75 \\
NRs. >20000 & 43 & 53.75 \\
\hline Marital Status & 32 & 40 \\
Married & 1 & 1.25 \\
Unmarried & 4 & 5 \\
Widowed & \\
Divorced & & \\
\hline
\end{tabular}


Table 2: Socio-cultural, familial and environmental factors $(n=80)$.

\begin{tabular}{|c|c|c|}
\hline Variables & Frequency & Percentage \\
\hline $\begin{array}{l}\text { Knowledge of family } \\
\text { members about illness } \\
\text { Physical } \\
\text { Psychological } \\
\text { Mental } \\
\text { Other }\end{array}$ & $\begin{array}{l}10 \\
21 \\
42 \\
7\end{array}$ & $\begin{array}{l}12.5 \\
26.25 \\
52.5 \\
8.75\end{array}$ \\
\hline $\begin{array}{l}\text { Cause of illness } \\
\text { Heredity } \\
\text { Disturbed brain chemicals } \\
\text { Psychological trauma } \\
\text { Spirits } \\
\text { Previous life's sin/deeds } \\
\text { Others }\end{array}$ & $\begin{array}{l}14 \\
23 \\
28 \\
8 \\
5 \\
2\end{array}$ & $\begin{array}{l}17.5 \\
28.75 \\
35 \\
10 \\
6.25 \\
2.5\end{array}$ \\
\hline $\begin{array}{l}\text { Belief whether treatable } \\
\text { Yes } \\
\text { No }\end{array}$ & $\begin{array}{l}64 \\
16\end{array}$ & $\begin{array}{l}80 \\
20\end{array}$ \\
\hline $\begin{array}{l}\text { Any role of families, } \\
\text { neighbors and relatives } \\
\text { Yes } \\
\text { No }\end{array}$ & $\begin{array}{l}68 \\
12\end{array}$ & $\begin{array}{l}85 \\
15\end{array}$ \\
\hline $\begin{array}{l}\text { Negative contribution by } \\
\text { people } \\
\text { Yes } \\
\text { No } \\
\text { On Yes response(n=61)* } \\
\text { Encourage for faith healing } \\
\text { instead of drug therapy } \\
\text { Ridiculed patient } \\
\text { Treat pt. as inferior } \\
\text { Said drugs are habit forming } \\
\text { Said mental illness never get } \\
\text { cured or treated } \\
\text { Misleading the family } \\
\text { Critical comments, over } \\
\text { involvement, hostility of } \\
\text { relatives }\end{array}$ & $\begin{array}{l}61 \\
19 \\
41 \\
6 \\
42 \\
26 \\
32 \\
40 \\
17\end{array}$ & $\begin{array}{l}76.25 \\
23.75 \\
\\
67.21 \\
9.87 \\
68.85 \\
42.62 \\
52.46 \\
65.57 \\
27.87\end{array}$ \\
\hline $\begin{array}{l}\text { Any significant life events } \\
\text { contributed to stop medicine } \\
\text { Yes } \\
\text { No }\end{array}$ & $\begin{array}{l}2 \\
78\end{array}$ & $\begin{array}{l}2.5 \\
97.5\end{array}$ \\
\hline $\begin{array}{l}\text { History of migration } \\
\text { Yes } \\
\text { No }\end{array}$ & $\begin{array}{l}3 \\
77\end{array}$ & $\begin{array}{l}3.75 \\
96.25\end{array}$ \\
\hline
\end{tabular}

Table 3 : Socio-cultural, familial and environmental factors $(\mathrm{n}=\mathbf{8 0})$

\begin{tabular}{|c|c|c|}
\hline Variables & Frequency & Percentage \\
\hline $\begin{array}{l}\text { Availability of } \\
\text { mental health } \\
\text { facility nearby home } \\
\text { Yes } \\
\text { No }\end{array}$ & $\begin{array}{l}22 \\
58\end{array}$ & $\begin{array}{l}27.5 \\
72.5\end{array}$ \\
\hline $\begin{array}{l}\text { Distance from } \\
\text { mental health centre } \\
\leq 5 \mathrm{~km} \\
5-10 \mathrm{~km} \\
10-20 \mathrm{~km} \\
20--40 \mathrm{~km} \\
>40 \mathrm{~km}\end{array}$ & $\begin{array}{l}7 \\
8 \\
24 \\
23 \\
18\end{array}$ & $\begin{array}{l}8.75 \\
10 \\
30 \\
28.75 \\
22.5\end{array}$ \\
\hline $\begin{array}{l}\text { Time taken to reach } \\
\text { hospital } \\
<1 \mathrm{hr} \\
2-3 \mathrm{hrs} \\
4-5 \mathrm{hrs} \\
>5 \mathrm{hrs}\end{array}$ & $\begin{array}{l}17 \\
33 \\
18 \\
12\end{array}$ & $\begin{array}{l}21.25 \\
41.25 \\
22.5 \\
15\end{array}$ \\
\hline $\begin{array}{lr}\begin{array}{l}\text { Ever } \\
\text { appointment } \\
\text { doctor }\end{array} & \begin{array}{r}\text { forget } \\
\text { of }\end{array} \\
\text { Yes } & \\
\text { No } & \end{array}$ & $\begin{array}{l}9 \\
71\end{array}$ & $\begin{array}{l}11.25 \\
88.75\end{array}$ \\
\hline $\begin{array}{l}\text { Stopped medication } \\
\text { as advised of faith } \\
\text { healer } \\
\text { Yes } \\
\text { No }\end{array}$ & $\begin{array}{l}8 \\
72\end{array}$ & $\begin{array}{l}10 \\
90\end{array}$ \\
\hline $\begin{array}{l}\text { Stopped treatment } \\
\text { due to social stigma } \\
\text { Yes } \\
\text { No }\end{array}$ & $\begin{array}{l}7 \\
73\end{array}$ & $\begin{array}{l}15 \\
85\end{array}$ \\
\hline $\begin{array}{l}\text { Monitoring patient } \\
\text { on medication } \\
\text { Yes } \\
\text { No } \\
\end{array}$ & $\begin{array}{l}68 \\
12 \\
\end{array}$ & $\begin{array}{l}85 \\
15 \\
\end{array}$ \\
\hline $\begin{array}{l}\text { Response of family } \\
\text { on refusal } \\
\text { Forcefully given } \\
\text { Mixed with food } \\
\text { Discontinue } \\
\text { treatment } \\
\text { Abused him/her } \\
\text { Take to hospital }\end{array}$ & $\begin{array}{l}24 \\
28 \\
9 \\
7 \\
72 \\
12\end{array}$ & $\begin{array}{l}30 \\
35 \\
11.25 \\
\\
8.75 \\
15\end{array}$ \\
\hline
\end{tabular}

\section{DISCUSSION:}

It is found that around half of patients with schizophrenia demonstrate non-compliance to treatment and a number of factors are associated with it. ${ }^{15}$ Demographic findings of the study show that majority $(40 \%)$ respondent were age group of 18 to 25 years and of them majorities were males $(57.5 \%)$. The study 
findings were concordance with past studies in which younger individual with Schizophrenia especially male have shown increase rate noncompliance.4,16,17 Approximately two third of patients are Hindu in our study. This is due to presence of large numbers of people with this religion in the locality. Approximately one seventh of the study subjects in our study were illiterate. Past studies explored the association of literacy with non-compliance and noncompliance was found more common among illiterate patients. 18,19 Approximately $60 \%$ of patients had family income of less than 10000 rupees a month. Poverty and financial issues are the risk factor for non-compliance. ${ }^{20,21}$

Socio-cultural , familial and environmental factors have significant role in the course of illness of schizophrenia. ${ }^{15}$ Around one fifth of family members did not have knowledge of illness and those who have, majority of them have wrong concept regarding the cause of illness. Similarly, one fifth of family members believed schizophrenia as untreatable illness. Understanding of patient and illness and relation between them determine the compliance. ${ }^{15}$ A significant proportion(15\%) of family members did not know role of them and relatives, and majority $(76.25 \%$ ) said that people contribute negatively by saying mental illness never get cured or treated, encourage for faith healer, treat patient inferior, mislead family, and showed expressed emotion. Considering these findings, it can be concluded that family members of the patient have lack of knowledge and awareness of illness and its consequences. Moreover this may be also due to attitude of people towards mental illness and socio-cultural belief. The probability of non-compliance and relapse increased when family members behavior tend to be over-involved, hostile and critical. ${ }^{22,23}$ Family members' knowledge and belief about illness is also crucial in determining compliance. ${ }^{5}$

The study showed that $2.5 \%$ of respondent have significant past life events that contributed them to stop medication. Life events have some association with treatment non-compliance. ${ }^{24} 3.75 \%$ of participants has history of migration during the journey of treatment. Social isolation, ${ }^{20,25}$ migration $^{24}$ during and prior to onset of illness increased the risk of non-compliance. Regarding access of mental health facility, majority $(72.5 \%)$ have no access nearby home, and majority $(81.25 \%)$ of them have to travel more than 10 kilometers for treatment. Similarly, more than one third of them had to spend more than 4 hours travel to access treatment. Considering this fact, majority of them have to spent time and money for travel apart from purchasing medication. Past study suggested that increased healthcare cost increased the rate of non-compliance and relapse. ${ }^{21}$ similarly, difficulty in accessing health services increased the risk of non-compliance..$^{20,26}$

Approximately one ninth of them forget appointment, $10 \%$ of them stopped medication as per advised of faith healer and $15 \%$ of them stopped medication due to social stigma. Similarly $15 \%$ of family members did not monitor the patient during medication and on refusal $11.25 \%$ of them stopped medication and $8.75 \%$ of them abused the patient. Looking to these findings, important factors associated in non-compliance in the study seems to be family, neighbour, relatives, economic, socio-cultural, education of mental health, and stigma etc. The study findings concordance with past studies finding. ${ }^{27,28}$ Nepal is a country with numerous cultures and traditions; however, each culture shares the same concepts regarding mental illness. ${ }^{29}$ Most of the people think that having mental illness is equivalent to being mad, becoming unfit to stay in family and society or even being possessed by a black magic or a holy spirit. ${ }^{30}$ Stigma and discrimination to persons with severe mental illness and their family members is common. This is the reason why that patient with mental illness hesitate to come forward for appropriate treatment. ${ }^{31}$ This stigma and lack of knowledge prevent patient from taking psychiatric medication. ${ }^{30}$ Due to poor economic condition they were not able to buy medication and even most of them prematurely stopped medication due to unawareness. Fleischhacker et $\mathrm{a}^{17}$ believed that patient having poverty and low education are more prone for non-compliance and relapse. Moreover, people even hesitate to buy medication openly due to strong stigma attached to mental disease. Most of the general population believes that mental illness is the result of bad fortune and people 
often seek help from local faith healers for a cure rather than mental health service. ${ }^{32}$

\section{CONCLUSION:}

The study explored noncompliance in Schizophrenia from socio-cultural, familial and environmental perspectives. Multiple factors were identified that contributed for noncompliance directly or indirectly. The noncompliance is a preventable condition that needs an emphasis from different perspectives. Efforts are needed to improve the compliance among patients with Schizophrenia. More emphasis should be given for patient and family education that helps to bring awareness of noncompliance and its consequences.

\section{CONFLICT OF INTEREST: None}

\section{REFERENCES:}

1. Patel KR, Cherian J, Gohil K, Atkinson D. Schizophrenia: Overview and Treatment Options. Pharmacy and Therapeutics. 2014;39(9):638-645.

2. Stip E, Tourjman V. Aripiprazol in Schizophrenia and Schizoaffective Disorder: A Review. ClinicalTherapeutics. 2010; 32:S3-S20.

3. Kazadi NJB, Moosa MYH, Jeenah FY. Factors associated with relapse in schizophrenia. SAJP 2008; 14:52-62.

4. Ghimire SR. Poor Medication Compliance in Schizophrenia from an Illness and Treatment Perspective. EC Psychology and Psychiatry 3(4); 2017: 131-141.

5. Sadock BJ, Sadock VA, Ruiz P. Kaplan E Sadock's Synopsis of Psychiatry. 11 th edn. Lippincott Williams $\mathcal{E}$ Wilkins 2014.

6. Zygmunt A, Olfson M, Boyer C, Mechanic D. Interventions to improve medication adherence in schizophrenia. Am J Psychiatry; 2002; 1653-1664.

7. Ghimire SR, Dhungana M, Bhagat S, Parajuli S. Health Promotion among Mentally Ill People in Nepal. J Psychiatric Association of Nepal. 2014;3(2):3-8.

8. Moritz S, Hünsche A, Lincoln TM. Nonadherence to antipsychotics: The role of positive attitudes towards positive

Neuropsychopharmacol. 2014;24:1745-1752. symptoms. Eur

9. Razali MS, Yahya H. Compliance with treatment in schizophrenia: A drug intervention program in a developing country. Acta Psychiatr Scand. 1995;91:331335.

10. Tranulis C, Goff D, Henderson DC, Freudenreich $O$. Becoming adherent to antipsychotics: A qualitative study of treatment-experienced schizophrenia patients. Psychiatr Serv. 2011;62:888-892.

11. Moritz S, Favrod J, Andreou C, Morrison AP, Bohn F, Veckenstedt $R$, et al. Beyond the usual suspects: Positive attitudes towards positive symptoms is associated with medication noncompliance in psychosis. Schizophr Bull. 2013;39:917-22.

12. Sultan S, Chary S, Vemula S. A study of noncompliance with pharmacotherapy in psychiatric patients. APJ Psychol Med. 2014;15:81-85.

13. Roy R, Jahan M, Kumari S, Chakraborty P. Reasons for drug non-compliance of psychiatric patients: A centre based study. J Indian Acad Appl Psychol. 2005;31:24-28.

14. World Health Organization. The ICD-10 Classification of Mental and Behavioural Disorders: Clinical Descriptions and Diagnostic Guidelines. Geneva: World Health Organization, 1992.

15. Gray R, Wykes T, Gournay K: From compliance to concordance: A review of the literature on interventions to enhance compliance with antipsychotic medication.J Psychiatr Ment health Nurs 2002; 9:277-284.

16. Srinivasan TN, Thara R: At issue: Management of medication noncompliance in schizophrenia by families in India. Schizophr Bull 2002; 28:537-542.

17. Fleischhacker WW, Oehl MA, Hummer M. Factors influencing compliance in schizophrenia patients. J Clin Psychiatry. 2003;64(16):10-13.

18. Olfson M, Marcus SC, Wilk J, West JC. Awareness of illness and nonadherence to antipsychotic medications among persons with schizophrenia. Psychiatr Serv. 2006;57:205-211.

19. Kane JM: Management strategies for the treatment of schizophrenia. J Clin Psychiatry 1999; 60(Suppl 12):13-17. 20. Perkins DO. Predictors of noncompliance in patients with schizophrenia. J Clin Psychiatry 2002; 63: 1121-1128. 21. Nicholl D, Akhras KS, Diels J, Schadrack J: Burden of schizophrenia in recently diagnosed patients: healthcare utilisation and cost perspective. Curr Med Res Opin 2010, 26:943-955.

22. Sadock BI, Sadock VA, Ruiz P. Kaplan E Sadock's Text Book of Psychiatry. Lippincott Williams E Wilkins 2009; 1:1656-1658.

23. Sadiq S, Suhail K, Gleeson J, Alvarez-Jimenez M. Expressed emotion and the course of schizophrenia in Pakistan. Soc Psychiatry Psychiatr Epidemiol. 2017; 52(5):587-593.

24. Bramon E, Murray RM. A plausible model of schizophrenia must incorporate psychological and social, as well as neurodevelopmental risk factors. Dialogues Clin Neurosci. 2001;3:243-256.

25. Gilmer TP, Dolder CR, Lacro JP, Folsom DP, Lindamer L, Garcia P, Jeste DV. Adherence to treatment with antipsychotic medication and health care costs among Medicaid beneficiaries with schizophrenia. Am J Psychiatry 2004; 161: 692-699.

26. Joe S, Lee JS. Association between non-compliance with psychiatric treatment and non-psychiatric service utilization and costs in patients with schizophrenia and related disorders. BMC Psychiatry. 2016;16:444.

27.Chandra IS, Kumar KL, Reddy MP, Reddy CMPK. Attitudes toward Medication and Reasons for NonCompliance in Patients with Schizophrenia. Indian Journal of Psychological Medicine. 2014; 36(3):294-298. 
28. Rao KN, George J, Sudarshan CY, Begum S. Treatment compliance and noncompliance in psychoses. Indian Journal of Psychiatry. 2017;59(1):69-76.

29.Acharya, AK. Knowledge, attitude and practice of mental illness in a village population. Department of Sociology and Anthropology, Tribhuvan University, Kathmandu, Nepal.1998

30. Regmi SK, Pokharel A, Ojha SP, Pradhan SN ,Chapagain G. Nepal mental health country profile. International Review of Psychiatry. 2004;16(1-2):142149.

31. Editorial. Mental health in Nepal. Nepalese J Psychiatry. 1999;1:3-4.

32. Shyangwa, PM, Singh S., Khandelwal SK. Knowledge and attitudes about mental illness among nursing staff. Journal of the Nepalese Medical Association. 2003;42:2731. 